\title{
Physical Child Abuse: What Are the External Factors?
}

\author{
Noremy, M. A. ${ }^{1}$, Zulkarnain, A. H. ${ }^{2}$, Kelvin, F. ${ }^{2}$, Adanan, M. J. ${ }^{3} \&$ Sarah, W. M. H. ${ }^{1}$ \\ ${ }^{1}$ School of Psychology and Human Development, Faculty of Social Sciences and Humanities, Universiti \\ Kebangsaan Malaysia, Bangi, Malaysia \\ ${ }^{2}$ School of Social Sciences, Universiti Sains Malaysia, Pulau Pinang, Malayisa \\ ${ }^{3}$ Faculty of Leadership and Management, Universiti Sains Islam Malaysia, Negeri Sembilan, Malaysia \\ Correspondence: Noremy, M. A., School of Psychology and Human Development, Faculty of Social Sciences \\ and Humanities, Universiti Kebangsaan Malaysia, 43600 UKM Bangi, Selangor, Malaysia. Tel: 60-12-340-1525. \\ E-mail: noremy@ukm.my
}

Received: June 4, $2012 \quad$ Accepted: June 16, $2012 \quad$ Published: July 16, 2012

doi:10.5539/ass.v8n9p83 URL: http://dx.doi.org/10.5539/ass.v8n9p83

\begin{abstract}
Children are an integral asset for future development of a nation. In lieu with this notion, countries pay much attention to their development and well being. In recent times, child abuse has been rampant. This issue is constantly making headlines in national newspapers in Malaysia. The alarming effect of this phenomenon is its inevitable implication on the family institution and the nation's aspiration to create a better tomorrow. This current study is an attempt to discover the contributory factors of physical child abuse in Malaysia. The objective of this study was to identify the background and demography of abuser and to identify the external factors that cause a parent to abuse their child. This case study was conducted in Selangor amongst eight Malay respondents using an in-depth interview session. This study found that external factors as the major contributory factor to physical child abuse. The factors are financial constraints, family crisis, character and disobedience of the children or so called 'deviant children', surroundings of the home, conflict with neighbours or lack of social support, parent's mental illness and and influence of alcohol. Hence these factors are articulated and interpreted by the researcher. Implications of this research, profession who work with children such as social worker, psycologist and counselor should look into the external factors that contribute to the physical child abuse in designing intervention, cure and effective strategies to overcome this problem. In future, protecting children needs collective effort from policy maker, authority body, non-government organization and member of society.
\end{abstract}

Keywords: physical abuse, children, parent, external factor, Malay family

\section{Introduction}

Children are crucial part of society, which are the country asset and the essence of future development. In 2008, there were 10.5 million (39.2\%) children out 27.7 million of Malaysia population (Zahir, 2010). As such, the government is concerned for the well being of the children. According to Giam (2001), the issue of abuse and neglect has declined in developed countries in the West like the United States and Britain. For example, in 2007, Child Protective Service in the United States has received 3.2 million cases of child abuse reports. Stunned results shows 80 per cent of those involved as the abusers are parent (U.S. Department of Health and Human Services, Administration on Children, Youth and Families, 2009). In fact, this issue also arises in the developing countries in the East like Thailand, Philippines and Malaysia. The issue of child abuse has become a global issue heavily discussed. It is not a new issue, but the rise of awareness towards the problems of child abuse is different from one country to another, and it always depends on the political, economic social and cultural in a country (Robert, 2008). In Malaysia, child abuse cases increasing each year. The number of cases reported to the Department of Social Welfare Malaysia increased to one thousand cases from 2001 to 2008; reaching 2, 780 cases in 2008. A person that is responsible as the abuser is dominated by the parent themselves (Department of Malaysian Social Welfare, 2009). It is an alarming situation since it has led to an erosion of the family institution because it can lead to implications that could threaten the stability of the country in an effort creates a caring society (Catherine and Kevin, 2002). Children are an important human capital to the nation and it must be develop to an optimum level by providing a safe and conducive environment (Mariatul, 2010). 
Referring to the Malaysia Child Act 2001'a child' is defined as anyone under the age of 18. Section 17(2) stipulates that a child is considered abused when there are substantive and overt signs of abuse on the child. It can be proven by laceration, concussion, abrasion, scars, rapture, dislocated or fractured bones, sprain, bleeding, a typical flow viscous, blisters from burning, aloofness or abrupt physical reactions, balding, or abnormal lost teeth. In accordance with Section 31 Act 611 states that custody of children including parent or care taker found guilty of child abuse or neglect, catapulting or exposing the children to physical or emotional injury, or sexual exploitation can be incarcerated for a maximum of 10 years and/or fined not more than RM 20,000 if found guilty (Jal Zabdi, 2010). Child abuse cases in Malaysia increase with a yearly upsurge. Cases reported at the Social Welfare Department Malaysia stood at a heightened figure of 2,780 for the corresponding year 2008 compared to 1,036 cases in 2001 (Statistical Report of Social Welfare Department Malaysia, 2008). Nevertheless, similar to the problems faced by other countries, official counts are more difficult to obtain due to the lack of awareness in reporting and incapability for the respective bodies to track child abuse cases. Child abuse cases remain highest in the state of Selangor, Malaysia. The steady rise of child abuse and abandonment cases in Malaysia was the rationale for this study, as it is deemed as a phenomenon that begged academic explanation. Current data available suggest that the state of Selangor, experiences the highest cases of child abuse and abandonment cases every year between 2001 and 2008, and this idealistically should provide sufficient information for an academic exploration.

\section{Literature Review}

Based on literature review carried out, there are many factors that lead someone be committing abuses against children. Belsky and Vondra (1989) has, identified four main factors that contribute to the risk of child physical abuse. There are demographic factors, family relationships, parenting features and characteristics of children themselves. Most of demographic factors related studies have given attention and focus on the effects of low socioeconomic status towards the risk of child abuse. Data from official reports and some survey shows family with low income tend to have higher rates and the potential to be involved in the case of child abuse (Gelles, 1989; Whipple and Webster-Stratton, 1991). It is also consistent with study by Zuravin and Greif (1989) in which the findings have emphasizes that there are strong relation between poverty and child abused.

Meanwhile Chan et al. (2006) also stated that parents involved in child physical abuse majority of them are with low income, low education background and have a large number of children. According to this study, the three aspects are interrelated because parents who do not have high educational background usually work with a modest income, and most of them have a large number of family members whereas the available monthly income is unable to sustain their lives. When faced with financial constraint and the various whims of the children and lack of knowledge and skills in managing stress, it will contribute to the occurrence of physical abuse cases against children.

Conger et al. (1994) found that economic restrain faced by parents in terms of psychological sides will enhance the emotional pressure where they are more easily furious, angry and prone to attack a child when they are in a state of tension. While Coohey (2006) states based on information reported to Child Protective Services (CPS) shows that abusers who commit a continuously crime of physical abuse against children is from those who are jobless. Therefore, Coohey (2006) concludes that unemployment is one factor that strongly associated with increased cases of physical abuse against family members, especially children. Accordingly, factor of unemployed respondents when combined with other risk factors such as having a large number of liabilities (Daly and Wilson, 1996) will place the family highly risky to be involved in child abused.

Lukianowicz (1971), in his study initially showed that there is significant relationship between parental involvements in physical abuse with marital relationship problems. Many abusers have problems in marriage and often arguments involved the children in which they ultimately become victims of domestic violence situation. When marriage couples have poor communication skills, domestic violence and physical abuse will increase (Christauria and Neil, 2008). According to Myung (2001), in relation to the conflict between the spouses, parents who had been abused by a partner or during childhood will tend to use an aggressive action toward their children when they were having conflict and releasing the resentment to the child, especially when the child committed the offense may invite the anger of the parents. Emiko (2000) also states that most studies of physical child abuse are common to a child who has parents who often disagreed, arguing and have marital problem.

Study has also shown that conflict between parents (Salzinger et al., 1992) and less social support (Whipple and Webster-Statton, 1991) are contribute to the risk of physical child abuse. While study by Joecelyn et al. (1998) has compiled a list of risk factors in the physical child abuse is by looking at demographic factor, family risk factor, parental risk factor and children who are at risk factor. The studies done have supported previous studies which finding shows the characteristics of family were at risk factors involved in physical abuse of children is the frequency of conflict and low quality marriage. Giligan (2000) explain that a good relationship, affection and 
mutual support are required by children for their well being. Instead, relationship that is characterized as unsafe and contain high levels of conflict can have negative effects on child development.

Environmental factors are important in the growth and development of the children. According to Shawna et al. (2008), the features and aspects of the home environment have been identified by previous studies; shows it's significantly associated with child abuse and neglect. Lohman et al. (2004) added, most of the children involved in physical abuse cases are living in an uncomfortable house and also in the neighborhood that has a similar condition. Normally, their home environment is more crowded, noisy, and family crises often occurred such as a fight between parents and sometimes conflict and arguments between parents and children. Furthermore, based on previous study, parents who live in such environment are more likely to use violence as a means to punish and discipline their children (Lohman et al., 2004).

In addition, house environment with low economic status is often associated with stress. Logically, the pressure faced by parents living in poverty is more severe and harmful if unwell controlled rather than those who live in the house environment with a high economic status. This high pressure indirectly affected both parent and children physically and mentally. Thus, this clearly shows that the in conducive house environment can lead to the occurrence of psychological problems and contribute to the physical child abuse (Grzywacs et al., 2004; Almeida et al., 2005; Gallo et al., 2006).

\section{Materials and Methods}

This study adopted the qualitative approach by using the descriptive technique. A purposive sampling method is utilized in this study as it is highly suitable for a qualitative research methodology in attaining an in-depth understanding of the subject matter (Gay and Airasian, 2000). Eight Malay families that were reported to the District of Social Welfare Department of Selangor for abandonment and physical child abuse were chosen as subjects for this study. After six interviews with eight respondents the saturation point was achieved. For validation of the saturation points, the researcher conducted two additional interviews. To achieve the objective of this paper, semi-structured interviews in an in-depth interview was used. The researcher developed some questions relevant to this discourse that pivotally was the beacon during the interview sessions. The interviewer also took notes during the interview sessions. For a systematical and accurate data analysis procedure, the thematic analysis was adopted according to the suggestion by Milles and Huberman (1984). Using this method a matrix table was derived in accordance with the themes and research questions matching the responses from the respondents. The matrix table facilitated the data analysis and furthermore made simple the process for comparisons of the themes and research questions by the individual respondents.

\section{Results and Discussion}

This study identified external factors that influence physical child abuse amongst Malay parents in Malaysia. These factors encompass the social system of the respondents. Table 1 shows a summary of background and demography of abuser. (see Table 1).

Table 1. Demographic background of abuser

\begin{tabular}{cclll}
\hline $\begin{array}{c}\text { Respondent } \\
\text { (R) }\end{array}$ & $\begin{array}{c}\text { Age } \\
\text { (years old) }\end{array}$ & Sex & Occupation & Relation with children \\
\hline R1 & 31 & Female & Housewife & Stepmother \\
R2 & 45 & Female & Clark & Stepmother \\
R3 & 34 & Female & Hawker & Biological mother \\
R4 & 38 & Female & Housewife & Biological mother \\
R5 & 28 & Male & Jobless & Stepfather \\
R6 & 36 & Female & Security guard & Biological mother \\
R7 & 26 & Female & Housewife & Stepmother \\
R8 & 44 & Male & Security guard & Biological father \\
\hline
\end{tabular}

The external factors included burden of financial constraints, domestic crisis or conflict in family, surroundings of home, conflict with neighbors, mental illness, the influence of alcohol and also the deviant child. The results in Table 2 show the factors that led Malay parents to physically abuse their children. (see Table 2). 
Table 2. External factors of respondents

\begin{tabular}{|c|c|c|c|c|c|c|c|c|c|}
\hline Factor & R1 & $\mathbf{R 2}$ & $\mathbf{R 3}$ & R4 & R5 & R6 & R7 & R8 & $\begin{array}{l}\text { Percentage } \\
(\%)\end{array}$ \\
\hline $\begin{array}{l}\text { Financial } \\
\text { constraints }\end{array}$ & $\sqrt{ }$ & & $\sqrt{ }$ & $\sqrt{ }$ & $\sqrt{ }$ & $\sqrt{ }$ & $\sqrt{ }$ & $\sqrt{ }$ & 87.5 \\
\hline Family crisis & & & & $\sqrt{ }$ & $\sqrt{ }$ & & $\sqrt{ }$ & $\sqrt{ }$ & 50.0 \\
\hline $\begin{array}{l}\text { Deviant } \\
\text { children }\end{array}$ & & $\sqrt{ }$ & $\sqrt{ }$ & & & $\sqrt{ }$ & $\sqrt{ }$ & & 50.0 \\
\hline $\begin{array}{l}\text { Surroundings } \\
\text { of home }\end{array}$ & & & & $\sqrt{ }$ & & $\sqrt{ }$ & $\sqrt{ }$ & & 37.5 \\
\hline $\begin{array}{l}\text { Conflict with } \quad \sqrt{ } \\
\text { neighbours }\end{array}$ & $\sqrt{ }$ & & & & $\sqrt{ }$ & & & & 37.5 \\
\hline $\begin{array}{l}\text { Mental } \\
\text { Illness }\end{array}$ & & $\sqrt{ }$ & & & & & & & 12.5 \\
\hline $\begin{array}{l}\text { Influence of } \\
\text { alcohol }\end{array}$ & & & & & $\sqrt{ }$ & & & & 12.5 \\
\hline
\end{tabular}

Note: $\mathrm{R}=$ Respondents

\subsection{Financial Constraints}

The majority of respondents $(87.5 \%)$ mentioned financial problems as a factor that drives them to acts of abusing the child. Not working and depending on the spouse's insufficient source of income and lackluster motivation was seen as contributing factor for the parent resorting to child abuse. Similarly, Conger et al. (1994) found that economic constraints faced by parents from the perspective of psychology increase emotional stress, which could lead to abrupt infuriation, anger, and also tendencies to channel this frustration towards their children when stressed. These findings are supported by a study in which parental behavior and socioeconomic status are seen to contribute significantly to the risk of abuse amongst mothers (Berger and Brooks-Gunn, 2005). Schuck and Widom (2005) contended that most cases of child abuse can be explained by looking at the underlying socio-economic factors, especially high poverty rates among parents that have many children.

However, amongst those interviewed, there was a single mother who stated that financial constraints was a major impediment when she had to do more than one work to fend for herself and her children after being abandoned by her husband. The respondent admitted to being depressed when faced with financial problems that seemed insurmountable and this indirectly drove her toward abusive demeanor. For example one single mother said,

"... I'm a widow, single mother, I have no one to depend on, and my monthly income depends on my stall in front of school. We five solely depend on that income. It is true when people said money is never enough when you think about it, but it never suffice for me, he (abused) asked for allowance which I don't have the money, suddenly 1 heard he go stealing at school, what kind of mother would not get angry?"

Another single mother added, "I got lots of responsibilities, seven kids, monthly salary is never enough. I even have to pay for my ex-husband debt. My ex-husband has disappeared, leaves the children alone with me. Sometimes it gives me headache when think about money. No idea where to get it."

This finding corroborated with the findings of Berger (2005) that in low-income families, economic earnings has the potential of prompting violence against children, most often amongst single mothers.

\subsection{Family Crisis}

The results illustrated that half of the respondents $(50 \%)$ stated that domestic conflict that occurred between them and the spouse was a contributing factor in cases of child abuse. The reasons for feud among spouses that were reported were financial problems and the existence of a surreptitious third party. Emiko (2000) contended that most studies of physical abuse of children demonstrate that physical violence, fighting, arguing and domestic conflicts often occur in the homes. For example a wife and a mother of two kids said,

"We always fight when it comes to money. When we are arguing I accidently hit the child. When she starts to cry, I hit her to release my anger at her father. I don't mean to hit her actually." 
A step father described one of his step sons this way, "If you like to know, this child (abused) is not my child. Out of blue his mother got pregnant, if I did not get married with her, I do not know what happened to this child (abused) and his mother. I'm willing to marry my wife but her never grateful to me about it, we always get into argument about her lazy attitude, and she doesn't even know how to take care of the children."

When there is a lack or inability to communicate among couples, tendencies of incidence of domestic violence and physical abuse will increase (Well and Ribner, 2008). For example, one respondent said "My wife does not agree the way I teach my children. That is why we always fight about the kids. When the kids being a nuisance or when I'm depressed I would hit them and my wife would interfere saying that I'm cruel. I just want to teach kids lesson, she just doesn't understand. That's why we always fight because she never understands what I do for my family."

Shawna et al. (2008) emphasized the importance of family relationships that will ultimately determine the pattern of parental behavior towards children. A healthy relationship among spouses will ultimately foster close relationships creating a stress-free supportive bond between the two and the family as a whole. Carlson et al. (2004) suggested that quality and positive emotional support in family relationships will form a stable marriage union reducing conflict and squabbles in the household. Positive parent-child relationships would ultimately reduce the physical abuse of children.

\subsection{Deviant Children}

This study found that half of the respondents (50\%) stated that children's misbehavior was the main factor that led to child abuse cases. Most parents expressed anger and stress that the child's mischievousness pushed their patience threshold and this led them towards taking action that was deemed inappropriate to the point of occurrences of child abuse. For example one mother described one of her son this way,

"There is one incident, which recorded by our neighbor's son via hand phone shows he (abused) wanted to jump out from the window, our house is on the fifth floor. Coincidently the window is broke due to him fighting with his sister. At that time I was back from work, I was so angry to see that record and I smack him with plastic pipe, I'm so mad, he just so naughty."

According to Daggett et al. (2000) parents have idealistic expectations on the development and growth of children; often believing that children are deliberately conducting negative behavior, hence, they deserve to be punished and eventually becoming victims of physical abuse. For example a step mother for two kids said,

"...among two of my stepdaughters, the youngest is the most spoiled (abused) and a bit naughty. She likes to bully her older disabled sister. These kids like to run away from house every time I and my husband fight. When I asked why, they said they afraid of getting hit. Sometimes they been gone for the whole day, due to a little fight I had with my husband. I remind them many times not to run away but they just being stubborn, it's like they asking for it."

In addition, Oates (1996) also stated that, children with behavioral problems are at higher risk of being abused. O'Keefe (1995) also found that children involved in cases of physical abuse have been identified as children who have behavioral problems such as aggression. However, most respondents excused themselves on grounds that their demeanor was solely to teach and discipline their children. Tajima (2000) noted that parents who have children with behavioral problems such as aggression, extreme mischievous characteristics or are involved in delinquency problems have double the risk of being physically chastised.

\subsection{Surroundings of Home}

The findings also suggested that $37.5 \%$ of the respondents found home environment was a factor of child abuse. A home that is uncomfortable, confined or boisterous will affect the attitudes and behavior of occupants in it. An inevitable occurrence of discomfort will dampen relationships of its occupants, and outburst of emotions due to irritation may cause the parent to abuse his or her child. For example one father stated,

"Our family lived in a two-story terraced low cost house. As you can expect, there's no comfortable place and space for the boys to play. These boys sure make a loud noise. I'm the type that sleep cannot be disturbed, one noise definitely make me mad. I'm tired back from work, all they know just arguing and fighting."

Suskind (1999) stated that juveniles who grew up in poverty struck surroundings are constantly burdened by environmental stress. These children are not only vulnerable to the lack of physical safety; but also live in crowded, uncomfortable and insufficiently adequate homes. Those who live in poverty are typically associated with a very stressful life and a non-conducive home environment, and this is contrary to those living in the high 
socio-economic status. Child abuse cases are uncommon amongst families with high socio-economic conditions. Unfavorable situations such as constriction, congestion and noise pollution situation could be factors inviting further pressure and potential for child abuse.

\subsection{Conflict with Neighbors}

A total of $37.5 \%$ of respondents admitted having problems with neighbors. The enmity among neighbors can occur in various illustrations and grounds. Among the cause of squabbles and disputes are envious grievances contributed by the contentment, comfort and luxury possessed by a neighboring family or personal problems involving children. The quandaries are usually trivial and with time these incidences are frowned on leading to a very hostile environment. In usual circumstances one party falls prey to isolation by others in the community and eventually the children often become victims of these conditions. For example one respondent who has personal problems with her neighbors said,

"...I and my neighbor never talk. She just can't accept us, saying that our family is troublesome."

Another respondent added, "I don't have good relationship with my neighbor. They really like to put their nose in other business, that why I don't want to be nice with them. Not to mention, they are good friends of my husband's ex-wife. I know sometimes they try to pry into our business via my step child (abuse). I bet they are the one who reported the case to JKM."

Family should not be separated from the social context, such as neighbors, communities and cultures. In fact, each of these is potential contributors to child abuse case. Referring to Garbarino (1995), neighborhood that tends to do damage and destroy community utilities and are prone to destruct the informal support systems such as relationships with friends and neighbors are viewed as having higher potentials of child abuse. Myung (2001) believes that a constructive relationship with neighbors would likely encourage social support that would help in strengthening social relationships within the neighborhood. Hence, if parents receive appropriate services and support from the community, not only will it improve the quality of family life, but it will also create an atmosphere of mutual support in the community of residence. Thus, it will reduce the risk of neglect and child abuse.

\subsection{Mental Illness}

One respondent reported mental state of mind as a cause of the incidence of child abuse. The respondent was admitted to the hospital due to psychiatric problems. Upon being released from hospital, the respondent was still dependent on sedatives to be able to function normally. However, the respondent claimed that he should not be burdened with too many tribulations and anxieties, due to his inclination to act out of control without considering potential risks to herself and those around her. A stressful mother with a mental disorder said,

"I can't take too many problems. All these thinking drive me crazy. Under these circumstances I'm not aware what I'm doing. He got critically smacked; I'm oblivious of what I'm doing."

Lovejoy et al. (2000) found that parents who experience high levels of stress develop hostility towards their children, creating a pessimistic relationship between them. Parents have tendencies or are inclined to use coercion instead of negotiations to control the behavior of their children (Cohn et al., 1990). Retrospectively, similar studies have also found that parents who experience high levels of stress tend to be at a greater risk of using aggression, compulsion and other forms of parenting strategies that resembles punishment. Parents who have mental illnesses not only have the potential for abusing children but are also at a greater risk of having continual negative interactions with their children and probably eventually neglecting them (Sydney et al., 1999).

\subsection{Influence of Alcohol}

One respondent claimed that drinking alcohol has influenced him to abuse his children physically. Excessive alcohol consumption caused the respondent to be in a drunken state, inevitably causing irrational behavior prompting him to act beyond control towards his children. According to Walsh et al. (2003), children whose parents are involved with substance abuse such as alcohol are twice at a higher risk of experiencing physical abuse. Parents who are involved in alcohol abuse are said to neglect constantly their children and have tendencies to fail in providing basic and proper care for their offspring (Hien et al., 2010). For example, an alcoholic father's stated,

"I'm an alcoholic. I spend every penny that I had to buy alcohol and get drunk. Maybe that's why we never had enough money. Old habits die hard. When I'm drunk I can't think rationally. That's why he (abused) got hit severely as I'm not really in control." 
Miller et al. (1999) argued that parents indulging in alcoholism have tendencies to abuse their children for their wrongdoings, and most often the punishments received are not corroborated with their bad behavior. Hien and Honeyman (2000) add that parents who are addicted to alcohol are found to be stricter in disciplining their children and are inclined to show authoritative characteristics to exert control over their children.

\section{Conclusion}

Based on the above findings and discussion, this paper revealed the major external factors that contributed to the physical child abuse such as financial constraints, family crisis, character and disobedience of the children or also called as deviant children, surroundings of home, conflict with neighbors or lack of social support, mental illness and influence of alcohol among parents.

This paper concludes that physical child abuse is one indicator of serious social illness in the society. Therefore children need to be protected from any form of abuse because they are critical assets for the future nation development. Understanding factors that contribute to the child abuse is crucial in designing effort and effective strategies to overcome the problem. In future, protecting children needs collective effort from policy maker, authority body, non-government organization and members of society.

In conclusion, physical abuse towards children inevitably collapses the family institution. Therefore, children should be protected from any form of danger, including torture, abuse, discrimination and exploitation in the forms of physical, social, emotional and mental stability. Children must also be equipped with appropriate values and attitudes to pursue the nation's goals and be future leaders.

\section{References}

Almeida, D. M., Neupert, S. D., Banks, S. R., \& Serido. (2005). Do daily stress processes account for socioeconomic health disparities? The Journals of Gerontology: Series B: Psychological Sciences and Social Science, 60B(2), 34-39. http://dx.doi.org/10.1093/geronb/60.Special_Issue_2.S34

Belsky, J., \& Vondra, J. (1989). Lessons from child abuse: The determinants of parenting. In D. Cicchetti \& V. Carison (Eds.), Current research and theoretical advances in child maltreatment (pp. 153-202). Cambridge, England: Cambridge University Press.

Berger, L. (2005). Income, family characteristics and physical violence toward children. Child Abuse \& Neglect, 29(2), 107-133. http://dx.doi.org/10.1016/j.chiabu.2004.02.006

Berger, L., \& Brooks-Gunn, J. (2005). Socioeconomic status, parenting knowledge and behaviors and perceived maltreatment of young low-birth-weight children. The Social Service Review, 79(2), 237-267. http://dx.doi.org/10.10861428957

Carlson, M., McLanahan, S., \& England, P. (2004). Union formation in fragile families. Demography, 41(2), 237-261. http://dx.doi.org/10.1353/dem.2004.0012

Catherine, H., \& Kevin, B. (2002). Predicting physical maltreatment in early. In K. D. Browne, H.Hanks, P. Stratton \& C. Hamilton (Eds.), Prediction and prevention of child abuse a handbook (pp. 41-56). United Kingdom, UK: John Wiley \& Sons, LTD.

Chan, Y.C., Gladys, L. T., Lam, P.K.R., \& Moon, T. E. S. (2006). Confirmatory factor analysis of the Child Abuse Potential Inventory: Results based on a sample of Chinese mothers in Hong Kong. Child Abuse \& Neglect, 30(9), 1005-1016. http://dx.doi.org/10.1016/j.chiabu.2006.05.005

Christauria, W., \& Neil, R. (2008). Healing from violence. New York, NY: Springer Publishing.

Cohn, J. F., Campbell, S. B., Matias, R., \& Hopkins, J. (1990). Face to face interactions of postpartum depressed and non-depressed mother-infant pairs at two months. Developmental Psychology, 26(1), 15-23. http://dx.doi.org/10.1037/0012-1649.26.1.15

Conger, R., Ge, X., Elder, G., Lorenz, F., \& Simons, R. (1994). Economic stress, coercive family process and developmental problems of adolescents. Child Development, 65, 541-561. http://dx.doi.org/10.1111/j.1467-8624.1994.tb00768.x

Coohey, C. (2006). Physically abusive father and risk assessment. Child Abuse \& Neglect, 30(5), 467-480. http://dx.doi.org/10.1016/j.chiabu.2004.10.016

Daggett, J., O’Brien, M., Zanolli, L., \& Peyton, V. (2000). Parents' attitudes about children: Associations with parental life histories and child-rearing quality. Journal of Family Psychology, 14(2), 187-199. http://dx.doi.org/10.1037/0893-3200.14.2.187 
Daly, M., \& Wilson, M. (1996). Violence against stepchildren. Current Directions in Psychological Sciences, 5(3), 77-80. http://dx.doi.org/10.1111/1467-8721.ep10772793

Department of Malaysian Social Welfare. (2009). National child policy and National child protection policy. Retrieved March 2, 2012 from http://www.jkm.gov.my/jkm/index.php?option=com_content\&view=article\&id=501:1592009-dasar-kanakkanak-negara-dan-dasar-perlindungan-kanak-kanak-negara\&catid=196:siaran-akhbar\&Itemid=28\&lang=ms

Emiko, A. T. (2000). The relative importance of wife abuse as a risk factor for violence againt children. Child Abuse \& Neglect, 24(11), 1383-1398. http://dx.doi.org/10.1016/S0145-2134(00)00194-0

Gallo, L. C., Smith, T. W., \& Cox, A. M. (2006). Socioeconomic status, psychosocial processes, and perceived health: An interpersonal perspective. Annuals of Behavioral Medicine, 31(2), 109-119. http://dx.doi.org/10.1207/s15324796abm3102_2

Garbarino, J. (1995). Growing up in a socially toxic environment: Life for children and families in the 1990s. In G. B. Melton (Ed.), Nebraska Symposium on Motivation: Vol. 42. The individual, the family and the social good: Personel fullfillment in times of change (pp. 1-20). Lincoln: University of Nebraska Press.

Gay, L. R., \& Airasian, P. (2000). Educational research: Competencies for analysis and application (6 ${ }^{\text {th }}$ ed.). New Jersey: Prentice-Hall.

Gelles, R. (1989). Child abuse and violence in single-parent families: Parent absence and economic deprivation. $\begin{array}{llll}\text { American Journal } & \text { of }\end{array}$ http://dx.doi.org/10.1111/j.1939-0025.1989.tb02738.x

Giam, C. C. (2001). Study of various factors on the potential of child abuse among selected Malays parents in the city of Kuala Lumpur. (Unpublished master's thesis). National University of Malaysia, Bangi Selangor.

Gilligan, R. (2000). Adversity, resilience and young people: The protective value of positive school and spare time experiences. In C. M. Chahal \& S. Coleman (Eds.), Safeguarding children and young people (pp. 37-47). New York, NY: Routledge.

Grzywacs, J. G., Almeida, D. M., Neupert, S. D., \& Ettner, S. L. (2004). Socioeconomic status and health: A micro-level analysis of exposure and vulnerability to daily stressors. Journal of Health and Social Behavior, 45(1), 1-16. http://dx.doi.org/10.1177/002214650404500101

Hien, D., \& Honeyman, T. (2000). A closer look at the maternal substances abuse-violence link. Journal of Interpersonal Violence, 15(5), 503-522. http://dx.doi.org/10.1177/088626000015005004

Hien, D., Cohen, L. R., Caldeira, N. A., Floam, P., \& Wasserman, G. (2010). Depression and anger as risk factors underlying the relationship between maternal substance involvement and child abuse potential. The International Journal: Child Abuse \& Neglect, 34(2), 105-13. http://dx.doi.org/10.1016/j.chiabu.2009.05.006

Jal Zabdi, M. Y. (2010). Crime of domestic violence (2nd ed.). Kuala Lumpur, Malaysia: Malaya University Publication.

Jocelyn, B., Patricia, C., Jeffrey G. J., \& Suzanne, S. (1998). A longitudinal analysis of risk factors for child maltreatment: Finding of a 17 year prospective study of officially recorded and self-reported child abuse and neglect. Child Abuse \& Neglect, 22(11), 1065-1078. http://dx.doi.org/10.1016/S0145-2134(98)00087-8

Lohman, B. J., Pittman, L. D., \& Coley, R. L. (2004). Welfare history, sanctions and developmental outcomes among low-income children and youth. Social Service Review, 78(1), 41-73. http://dx.doi.org/10.1086/380767

Lovejoy, M., Graczyk, P., O’ Hare, \& Neuman, G. (2000). Maternal depression and parenting behavior: A

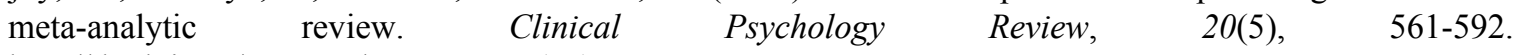
http://dx.doi.org/10.1016/S0272-7358(98)00100

Lukianowicz, N. (1971). Battered children, psychiatrica clinica. In B. Corby (Ed.), Child abuse toward a knowledge base (pp. 257-280). United State of America, USA: Open University Press.

Mariatul, Q. Z. (2010). Child policy for all. Retrieved March 5, 2012, from http://www.utusan.com.my/utusan/info.asp?y=2010\&dt=0429\&pub=Utusan_Malaysia\&sec=Keluarga\&pg $=\mathrm{ke} \_01 . \mathrm{htm}$ 
Miller, B., Smyth, N., \& Mudar, P. (1999). Mothers' alcohol and other drug problems and their punitiveness toward children. Journal of Studies on Alcohol, 60(5), 632-642.

Milles, M. B., \& Huberman, A. M. (1984). Qualitative data analysis. Beverly Hill: SAGE Publication Inc.

Myung, S. P. (2001). The factors of child physical abuse in Korean immigrant families. Child Abuse \& Neglect, 25(7), 945-958. http://dx.doi.org/10.1016/S0145-2134 (01)00248-4

O' Keefe, M. (1995). Predictors of child abuse in maritally violent families. Journal of Interpersonal Violence, 10(1), 3-25. http://dx.doi.org/10.1177/088626095010001001

Oates, K. (1996). The spectrum of child abuse: Assessment, treatment, and prevention. New York: Brunner/Mazel, Inc.

Robert, S. F. (2008). Adolescence. United State of America, USA: Pearson.

Salzinger, S., Feldman, R. S., Hammer, M., \& Rosario, M. (1992). Constellations of family violence and their differential effects on children's behavioral disturbance. Child \& Family Behavior Therapy, 14(4), 23-41. http://dx.doi.org/10.1300/J019v14n04_03

Schuck, A., \& Widom, C. (2005). Understanding the role of neighborhood context in the long term criminal consequences of child maltreatment. American Journal of Community Psychology, 36(3/4), 207-222. http://dx.doi.org/10.1007/s10464-005-8615-1

Shawna J. L., Neil B. G., \& Yookyong, L. (2008). Risk factors for paternal physical child abuse. Child Abuse and Neglect, 32(9), 846-858. http://dx.doi.org/10.1016/j.chiabu.2007.11.006

Statistical Report of Social Welfare Department Malaysia. (2008). Kuala Lumpur.

Suskind, R. (1999). A hope in the unseen: An American odyssey from the inner city to the Ivy League. New York: Broadway Books.

Sydney, L., Victor, J., \& Linda, G. (1999). The role of psychopathology in the parenting of drug-dependent $\begin{array}{llll}\text { women. Development and Psychopathology, 11(4), } & \text { 957-977. }\end{array}$ http://dx.doi.org/10.1017/S0954579499002400

Tajima, E. A. (2000). The relative importance of wife abuse as a risk factor for violence against children. Child Abuse \& Neglect, 24(11), 1383-1398. http://dx.doi.org/10.1016/S0145-2134(00)00194-0

US Department of Health and Human Services, Administration on Children, Youth and Families. (2009). Child maltreatment 2007. Washington, DC: US Goverment Printing Office. In Denise, H., Lisa R. C., Nathilee A. C., Peter, F., \& Gail,W., Depresion and anger as risk factors underlying the relationship between maternal substance involvement and child abuse potential. The Internaional Journal of Child Abuse and Neglect, 34(2), 105-133. http://dx.doi.org/10.1016/j.chiabu.2009.05.006

Walsh, C., MacMillan, H., \& Jamieson, E. (2003). The relationship between parental substances abuse and child maltreatment: Findings from the Ontario Health Supplement. Child Abuse \& Neglect, 27(12), 1409-1425. http://dx.doi.org/10.1016/j.chiabu.2003.07.002

Well, C., \& Ribner, N. (2008). Healing from violence. New York: Springer Publishing.

Whipple, E. E., \& Webster-Stratton, C. (1991). The role of parental stress in physically abusive families. Child Abuse \& Neglect, 15(3), 279-291. http://dx.doi.org/10.1016/0145-2134(91)90072-L

Zahir, Z. (2010). National of child policy. Retrieved February 22, 2012, from http://zahirzainudin.blogspot.com/2010/03/dasar-kanak-kanak-negara.html

Zuravin, S. J., \& Greif, G. (1989). Normative and child-maltreating AFDC mothers. Social Casework. The Journal of Contemporary Social Work, 70(2), 76-84. http://dx.doi.org/10.1606/0037-7678.1906 